\author{
ACTA AGROBOTANICA \\ Vol. 63 (2): 57-67 \\ 2010
}

\title{
THE SPECIES RICHNESS OF THE FLORA OF SELECTED SECTIONS OF THE MIETIUŁKA RIVER IN THE POLESIE NATIONAL PARK
}

\author{
Magdalena Pogorzelec \\ Department of General Ecology, University of Life Sciences, Akademicka 15, 20-950 Lublin, Poland \\ e-mail: magdalena.pogorzelec@up.lublin.pl
}

Received: 16.11 .2009

\begin{abstract}
The aim of the study was to conduct an environmental evaluation of 6 selected sections of the improved Mietiulka River, which included an inventory and analysis of the vascular flora associated directly with this watercourse. The results of the study have shown that the flora of the study area is diverse in taxonomic, syntaxonomic and ecological terms, and that it comprises both typical aquatic plants and species characteristic of the habitats surrounding the river. In the flora found in the study sectors, a total of 114 vascular plant species was identified, which come from 42 botanical families, 15 syntaxonomic classes and belong to different ecological groups. Hemicryptophytes, spontaneophytes, species neutral to continentality as well as species included in the phytochorion with boreal elements: Euro-Siberian subelement, were clearly predominant in the species composition of the flora of all the study sectors. The macrophytes commonly found in Poland had the largest proportion. One species with a small number of stands in the country - water dropwort (Oenanthe fistulosa) - as well as two species threatened with extinction, Sagittaria sagittifolia and Hypochoeris glabra, were recorded.
\end{abstract}

Key words: vascular flora, improved river, Mietiułka River, Polesie National Park

\section{INTRODUCTION}

The Mietiułka River is a small, anthropogenically transformed watercourse, flowing through the northern part of the Polesie National Park (PNP). This river is situated on the eastern side of the watershed running through the Park (in the Bug River basin), and its catchment area is estimated to be 3,965.8 ha. The river originates in the area of Pieszowola, right by the Park boundary, and it feeds into the Włodawka River upstream of Lake Wytyckie. The total length of the river within the Park is $9.25 \mathrm{~km}(\mathrm{Cebrykow}$ et al. 2001; Michalczy k et al. 2002).
Little direct information on the Mietiułka River itself can be found in literature. The typically anthropogenic nature of its channel is a result of land drainage improvements carried out in the second half of the 20th century (Łoś, 1992; 1995). The Mietiulka belongs to the rivers in which the banks have been levelled out and most of the river bank shrubs, which protect against overheating in the summer period and overcooling outside the growing season, have been removed (K ornijów, 1999). Due to the location of the river in a natural depression in the land surface and agricultural use of the area around the Park, the waters carried by the Mietiułka River are characterized by a high content of dietary minerals and anthropogenic substances, which has a negative effect on its natural values (J a n i e c, 1994; M i c h a l c z y k et al. 1999).

It was only in 1994 that the Mietiułka River, together with its adjacent area, was included in the Polesie National Park. Since that time, renaturalization work has been carried out, designed to gradually increase water storage and to improve the quality of the waters. The aim of these efforts is to create appropriate habitat conditions for different flora and fauna species in the river and within the area adjacent to the river channel (Chmielewski and Sielewicz, 1994; Pias e cki, 2005).

The aim of the presented pilot study was to conduct an environmental evaluation of 6 selected sections of the improved Mietiułka River, which included an inventory and analysis of the vascular flora associated directly with this watercourse.

\section{MATERIALS AND METHODS}

The pilot field study was carried out in May and July 2006 in the Polesie National Park. The study area covered the northern part of the Park, through which the Mietiułka River flows. 
During the first stage of the field investigations, a site visit was conducted in the study area, which was designed to make a preliminary identification of vegetation cover and its variation along the studied watercourse. Subsequently, six study sectors were established (I - VI; Fig. 1), each with a length of $25 \mathrm{~m}$. The selection of the location of the sectors was guided by the variation in the vegetation cover and the habitats bordering the investigated watercourse (Figs 2, 3, 4).

The status of the flora in particular study sectors was documented, by making and analysing species inventories. The plant species were identified using the key of Rutk ow ski (2001). Botanical nomenclature followed Mire k et al. (2002). The plant species present in the study sectors were assigned to syntaxonomic classes (M a tus zki ewicz, 2001). In office investigations, Ekologiczne liczby wskaźnikowe roślin naczyniowych (Ecological indicator values of vascular plants) (Zarzycki et al. 2002) was used to determine the proportion of species of different ecological groups, life forms and the degree of their endangerment. The species were assigned to historical-geographical groups and range groups according to Ch miel (1993). Jaccard's formula (W y s o c ki and $\mathrm{S}$ i k o r s k i , 2002) was used to calculate the index of species similarity in the flora of the study sectors.

\section{RESULTS}

In the phytocoenoses of all the study sectors, a total of 114 vascular plant species was identified, representing 42 botanical families. The most numerous was the group of species from the families Poaceae (14 species) and Asteraceae (10 species). The greatest species richness of the vascular flora was noted in sectors I and II (47 species in each $-52.8 \%$ of all the taxa). In sector I, Calluna vulgaris, Vicia cracca, Arrhenatherum elatius, Lysimachia vulgaris as well as Filipendula ulmaria occurred in greatest numbers. Carex rostrata, Equisetum fluviatile, Stratiotes aloides, and Lemna minor predominated in sector II (Table 1).

The lowest species richness was noted in sector IV (19 species), which was attributable to extensive shading of the surface of this sector's area by the forest neighbouring with the watercourse in question. There was noted a clear dominance of Urtica dioica on the slopes of the watercourse, as well as of Lemna minor and Spirodela polyrhiza in the water.

The species such as Elodea canadensis, Lemna minor, Filipendula ulmaria and Urtica dioica were found in all the study sectors. The species similarity index for the flora in most of the study sectors was low (between 0.09 and 0.38); only the phytocoenoses of sectors $\mathrm{V}$ and VI showed a significant similarity at a level of 0.57 (Table 2).
The species of the syntaxonomic class MolinioArrhenatheretea were clearly predominant in the species composition of the flora in sector I; this class had twice more representatives in this sector than the second ranking Phragmitetea. Almost a half of the taxa found in sector II belonged to the class Molinio-Arrhenatheretea. In sector III, the classes Phragmitetea and Molinio-Arrhenatheretea were represented in greatest numbers. The species of the class Lemnetea minoris had a large proportion in the phytocoenosis of this sector $(11.8 \%)$, similarly in sector IV $(10.5 \%)$. It was likewise in the case of the class Potametea (the proportion of the characteristics species in the flora of sector III $-11.8 \%$, in sector IV - $21.1 \%$ ).

In sector IV, the largest number of species was recorded from the class Potametea $(21.1 \%)$. There were fewer representatives of the following classes $(15.8 \%$ of each class): Phragmitetea, Molinio-Arrhenetheretea and Querco-Fagetea (with no clear dominance of the species of any of these classes). In sectors V and VI, the species characteristic of the classes Molinio-Arrhenetheretea and Phragmitetea clearly dominated.

The results of the analysis of the floristic composition and the proportions of particular species in the flora of the investigated sites did not allow an exact classification of the syntaxa to be made due to the absence of characteristic combinations of species. The associations of the aquatic macrophytes LemnoSpirodeletum polyrhizae, encountered in sectors III, V and VI, were the only exception.

The analysis of the life-form spectrum of the flora showed that it was typical of this geographical zone. Hemicryptophytes (plants with perennating buds at the soil surface) clearly dominated in the species composition of the flora of all the sectors located on the Mietiułka River. Geophytes (plants with perennating buds lying in dry ground), together with hydrophytes and helophytes classified as cryptophytes (plants with perennating buds lying beneath the ground or submerged under water), accounted for a relatively small percentage of the taxa identified. The taxa belonging to phanerophytes (plants with perennating buds borne on aerial shoots) occurred only in three sectors, with the most numerous group noted in sector IV (Table 3 )

Few chamaephytes (plants with perennating buds borne close to the ground) occurred in five sectors, and the only recorded representative of woody chamaephytes was Calluna vulgaris.

In addition to the life-forms distinguished by Raunkiaer, with reference to the adaptation of plants to survive the unfavourable season ( $\mathrm{S} \mathrm{z}$ a f e r, 1964; F a li ń s k a, 2004), the classification adopted for the purpose of the analysis (Z a r z y c k i et al. 2002) also comprised other groups, including semi-autrotrophs, the only representative of which is Melampyrum pratense (a species also belonging to the group of therophytes) found in sector II. 
Table 1

The species composition of the vascular flora of the phytocoenoses of particular study sectors

\begin{tabular}{|c|c|c|c|c|c|c|}
\hline \multirow{2}{*}{ Species } & \multicolumn{6}{|c|}{ Sectors } \\
\hline & I & II & III & IV & $\mathrm{V}$ & VI \\
\hline Achillea millefolium & & + & & & & \\
\hline Acorus calamus & & & + & & & \\
\hline Alisma plantago aquatica & + & & & & + & + \\
\hline Alnus glutinosa & & & & + & & \\
\hline Alopecurus pratensis & & & + & & & + \\
\hline Anthoxanthum odoratum & + & & & & & \\
\hline Arrhenatherum elatius & + & + & + & & & \\
\hline Artemisia vulgaris & & & + & & & \\
\hline Batrachium aquatile & + & & & & & \\
\hline Berula erecta & & & & & + & + \\
\hline Betula pendula & + & & & & & \\
\hline Calamagrostis canescens & & & + & & & + \\
\hline Calluna vulgaris & + & & & & & \\
\hline Caltha palustris & + & + & & & & \\
\hline Capsella bursa-pastoris & + & & & & + & + \\
\hline Cardamine pratensis & + & & + & & + & + \\
\hline Carex hirta & + & & & & & \\
\hline Carex pseudocyperus & + & & + & & & \\
\hline Carex rostrata & & + & + & & & \\
\hline Carpinus betulus & & & & + & & \\
\hline Ceratophyllum demersum & . & + & + & + & & \\
\hline Chamaenerion angustifolium & + & + & & & & \\
\hline Cirsium palustre & + & + & & & & \\
\hline Comarum palustre & & + & & & & + \\
\hline Conyza canadiensis & + & & & & & \\
\hline Cynosurus cristatus & & + & & & & \\
\hline Dactylis glomerata & & & & & + & \\
\hline Eleocharis palustris & & & + & & & \\
\hline Elodea canadensis & + & + & + & + & + & + \\
\hline Epilobium palustre & & & & & + & + \\
\hline Equisetum fluviatile & & + & & & & \\
\hline Equisetum palustre & + & & + & & & \\
\hline Eupatorium cannabinum & & & & & + & \\
\hline Fectuca rubra & & & & & + & \\
\hline Filipendula ulmaria & + & + & + & + & + & + \\
\hline Galeobdolon luteum & & & & + & & \\
\hline Galium aparine & & + & & & & \\
\hline Galium mollugo & + & & & & & \\
\hline
\end{tabular}

\begin{tabular}{|c|c|c|c|c|c|c|}
\hline \multirow{2}{*}{ Species } & \multicolumn{6}{|c|}{ Sectors } \\
\hline & I & II & III & IV & $\mathrm{V}$ & VI \\
\hline Geranium robertianum & & & & + & & \\
\hline Glechoma hederaceae & & & & & + & + \\
\hline Helichrysum arenarium & + & & & & & \\
\hline Hieracium pilosella & + & & & & & \\
\hline Hydrocharis morsus ranae & & & + & & + & + \\
\hline Hypericum perforatum & + & + & & & & \\
\hline Hypocheris glabra & + & & & & & \\
\hline Juncus conglomeratus & & + & & & & \\
\hline Juncus effusus & + & + & & + & & \\
\hline Lamium maculatum & & + & & & & \\
\hline Lathyrus pratensis & & + & & & & \\
\hline Lemna minor & + & + & + & + & + & + \\
\hline Lemna trisulca & & + & + & & + & + \\
\hline Lolium perenne & & + & & & + & \\
\hline Lychnis flos-cuculi & + & & & & & \\
\hline Lycopus europaeus & + & + & & & & \\
\hline Lysimachia nummularia & & + & & & + & \\
\hline Lysimachia vulgaris & + & + & + & & + & + \\
\hline Lythrum salicaria & + & + & + & & + & + \\
\hline Medicago lupulina & & & & & + & \\
\hline Melampyrum pratense & & + & & & & \\
\hline Melandrium album & + & & + & & + & + \\
\hline Molinia coerulea & & & & & + & \\
\hline Myosotis palustris & + & + & & & + & + \\
\hline Myriophyllum verticillatum & & + & & & & \\
\hline Nuphar lutea & & & & & + & + \\
\hline Oenanthe fistulosa & & & & & + & + \\
\hline Oxalis fontana & & & & + & & \\
\hline Paris quadrifolia & & & & + & & \\
\hline Peucedanum palustre & + & & & & & \\
\hline Phalaris arundinaceae & + & & + & & + & + \\
\hline Phleum pratense & & + & + & & & + \\
\hline Phragmites australis & & & & + & + & + \\
\hline Pinus sylvestris & + & & & & & \\
\hline Plantago lanceolata & & + & & & & \\
\hline Plantago major & & + & & & & \\
\hline Poa palustris & & & + & & & + \\
\hline Poa trivialis & & + & & & & \\
\hline
\end{tabular}


cd. Table 1

\begin{tabular}{|c|c|c|c|c|c|c|}
\hline \multirow{2}{*}{ Species } & \multicolumn{6}{|c|}{ Sectors } \\
\hline & I & II & III & IV & $\mathrm{V}$ & VI \\
\hline Potamogeton natans & & & & + & & \\
\hline Potentilla anserina & + & + & + & & + & + \\
\hline Potentilla argentea & + & & & & & \\
\hline Prunella vulgaris & & & & & & + \\
\hline Pyrus communis & & + & & & & \\
\hline Ranunculus flammula & & + & & & & \\
\hline Ranunculus lingua & & + & & & & \\
\hline Ranunculus repens & & & & & & + \\
\hline Rorippa amphibia & & & & & + & + \\
\hline Rumex hydrolapathum & + & + & & & + & + \\
\hline Sagittaria sagittifolia & & & & + & + & + \\
\hline$\underline{\text { Salix cinerea }}$ & + & + & & & & \\
\hline Scirpus sylvaticus & & + & & + & + & + \\
\hline Scleranthus perennis & + & & & & & \\
\hline Scutellaria galericulata & + & + & + & & + & \\
\hline Solanum dulcamara & & & & & + & \\
\hline Sparganium emersum & & & + & & & \\
\hline
\end{tabular}

\begin{tabular}{|c|c|c|c|c|c|c|}
\hline \multirow{2}{*}{ Species } & \multicolumn{6}{|c|}{ Sectors } \\
\hline & I & II & III & IV & $\mathrm{V}$ & VI \\
\hline Sparganium erectum & & & + & + & + & + \\
\hline Spirodela polyrhiza & & & + & + & + & + \\
\hline Stellaria graminea & + & + & & & + & + \\
\hline Stratiotes aloides & & + & + & + & + & \\
\hline Tanacetum vulgare & & & & & & + \\
\hline Thalictrum flavum & & & & & & + \\
\hline Trifolium arvense & + & & & & & \\
\hline Trifolium repens & & + & & & & \\
\hline Typha latifolia & & + & & & & \\
\hline Urtica dioica & + & + & + & + & + & + \\
\hline Veronica anagallis-aquatica & + & & & & & \\
\hline Veronica beccabunga & + & & & & & + \\
\hline Veronica chamaedrys & & + & & & & \\
\hline Vicia cracca & + & & + & & + & + \\
\hline Viola arvensis & + & & & & & \\
\hline Viola palustris & + & & & & & \\
\hline Wolffia arrhiza & & & + & & & \\
\hline
\end{tabular}

Table 2

Jaccard's species similarity index for the phytocoenoses of the study sectors (1-6)

\begin{tabular}{cccccc}
\hline Study sectors & 2 & 3 & 4 & 5 & 6 \\
\hline 1 & 0.25 & 0.23 & 0.08 & 0.24 & 0.25 \\
\hline 2 & & 0.21 & 0.09 & 0.20 & 0.18 \\
\hline 3 & & 0.17 & 0.33 & 0.38 \\
\hline 4 & & & 0.20 & 0.18 \\
\hline 5 & & & & & 0.57 \\
\hline
\end{tabular}

The analysis of the flora of the study sectors as an indicator of continentality showed that the species neutral to continentality were by far predominant (Table 4).

Spontaneophytes, the species which arrived or are native to the area and can exist there without human intervention, had the largest proportion $(88.6 \%)$ in the flora of the study area. Anthropophytes, synanthropic plant species of foreign origin in a given area, occurring both in secondary, artificial habitats formed as a result of human activity and in semi-natural or natural habitats, accounted for $5.3 \%$ of the studied flora (Table 3).

Based on the classification adopted by Chmiel (1993a), the plant species found in the study sectors were representatives of different range elements, but the species included in the phytochorion with boreal elements: Euro-Siberian subelement, accounted for the largest number (ES; 29\%). A large proportion of cosmopolitan species was also noted (21.9\%; Table 4).

In the phytocoenoses of all the study sectors, the macrophytes commonly found in Poland had the largest proportion. In sectors $\mathrm{V}$ and $\mathrm{VI}$, one species with a small number of stands in the country - water dropwort (Oenanthe fistulosa; Table 5) - was recorded. In sectors IV, V and VI, the occurrence of Sagittaria sagittifolia was noted, whereas in sector I Hypochoeris glabra, species threatened with extinction ( $\mathrm{Z}$ a r z y c ki et al. 2002). 


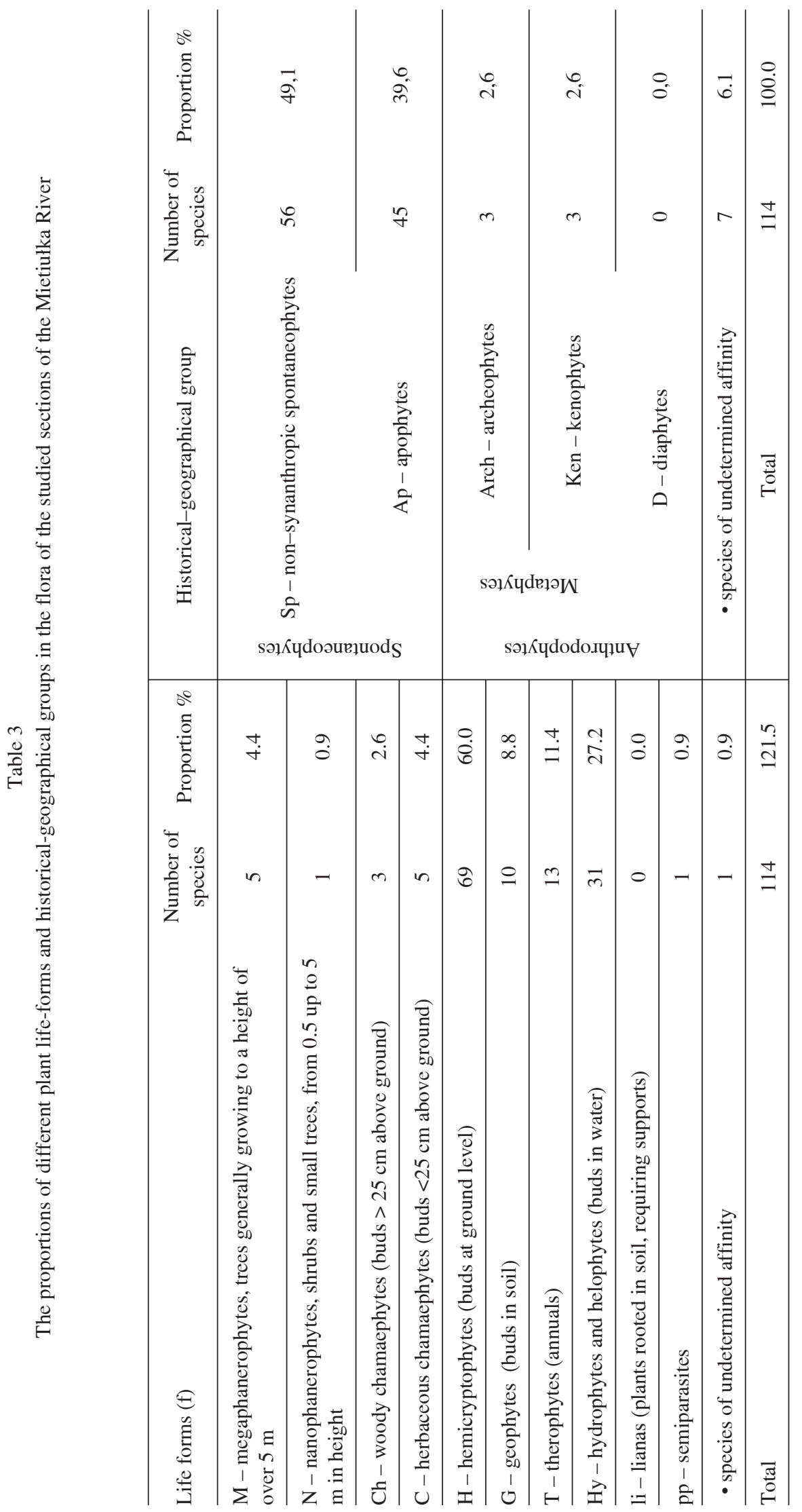




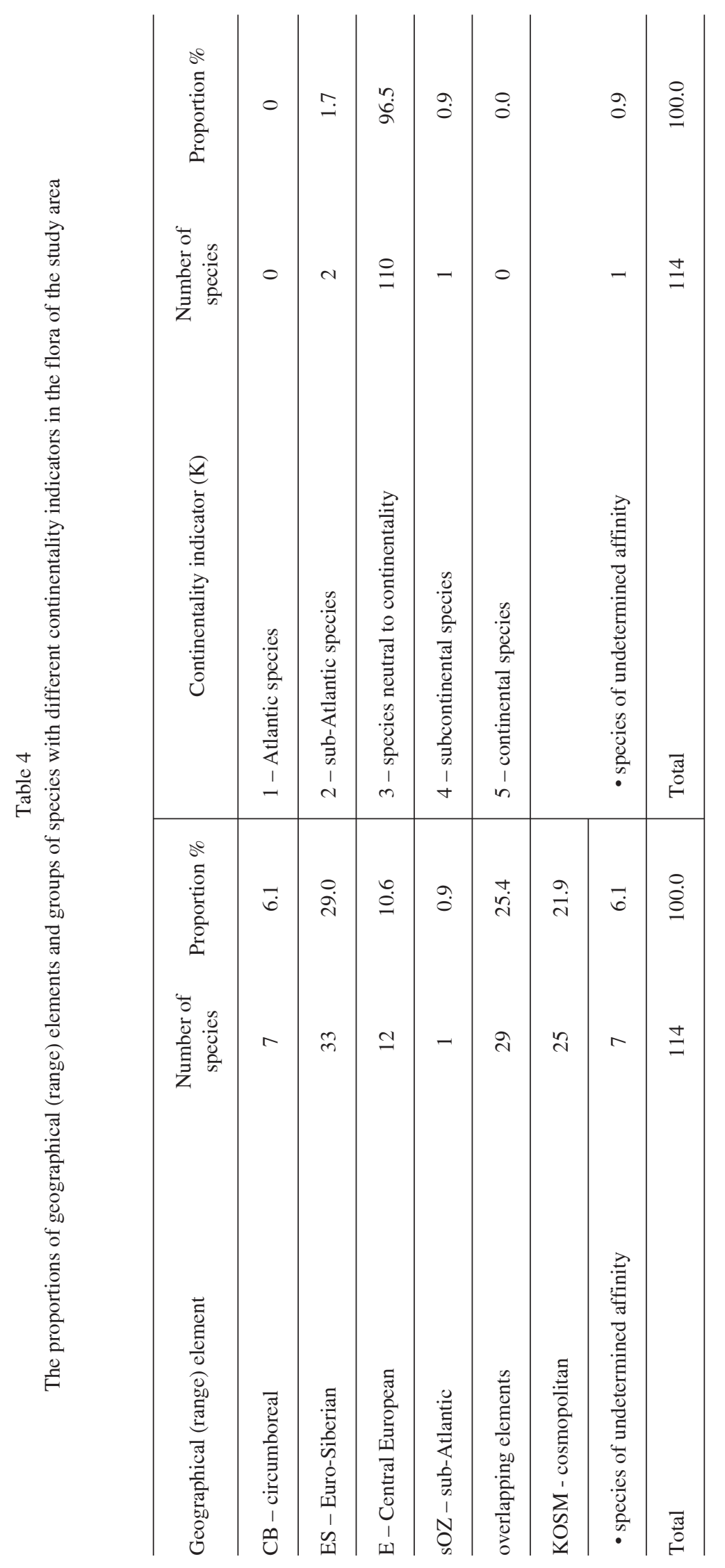




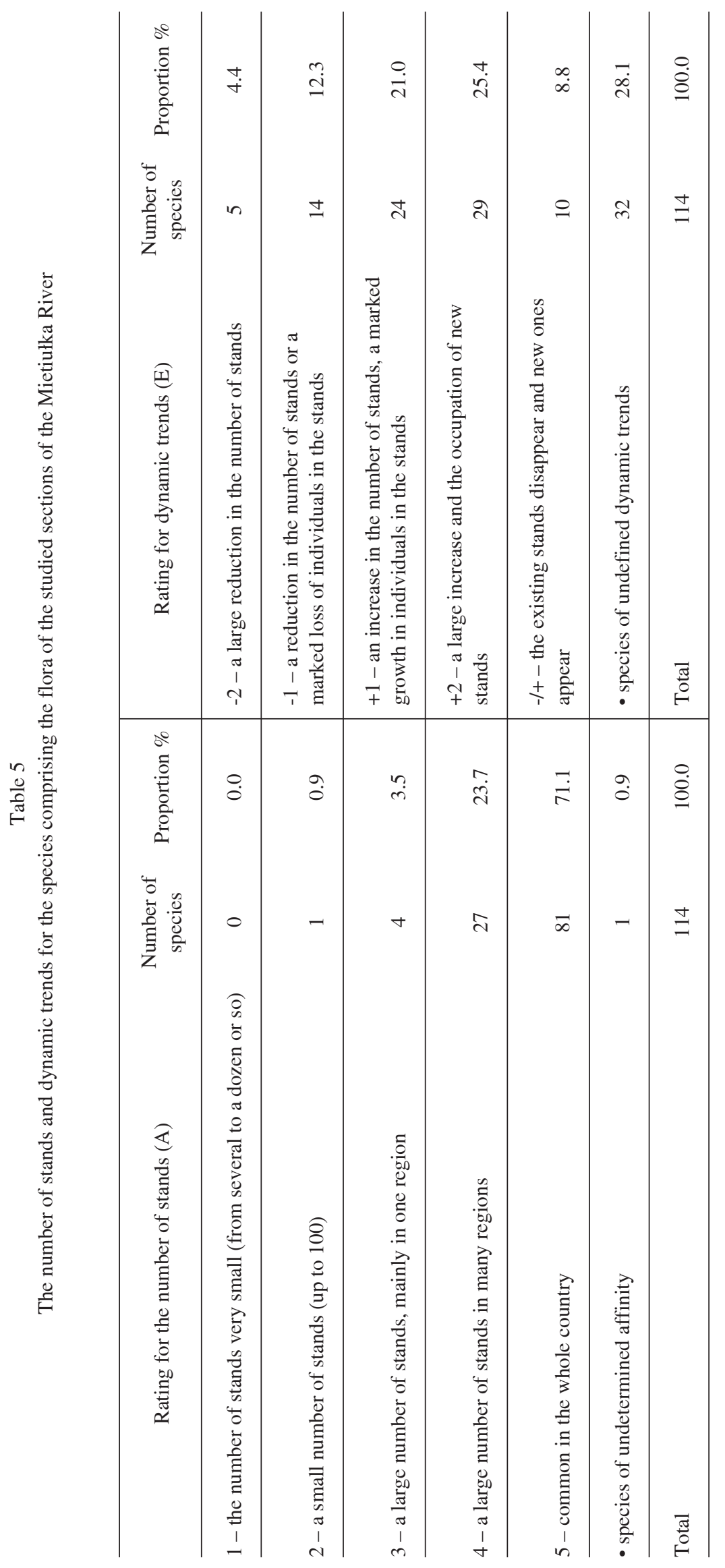




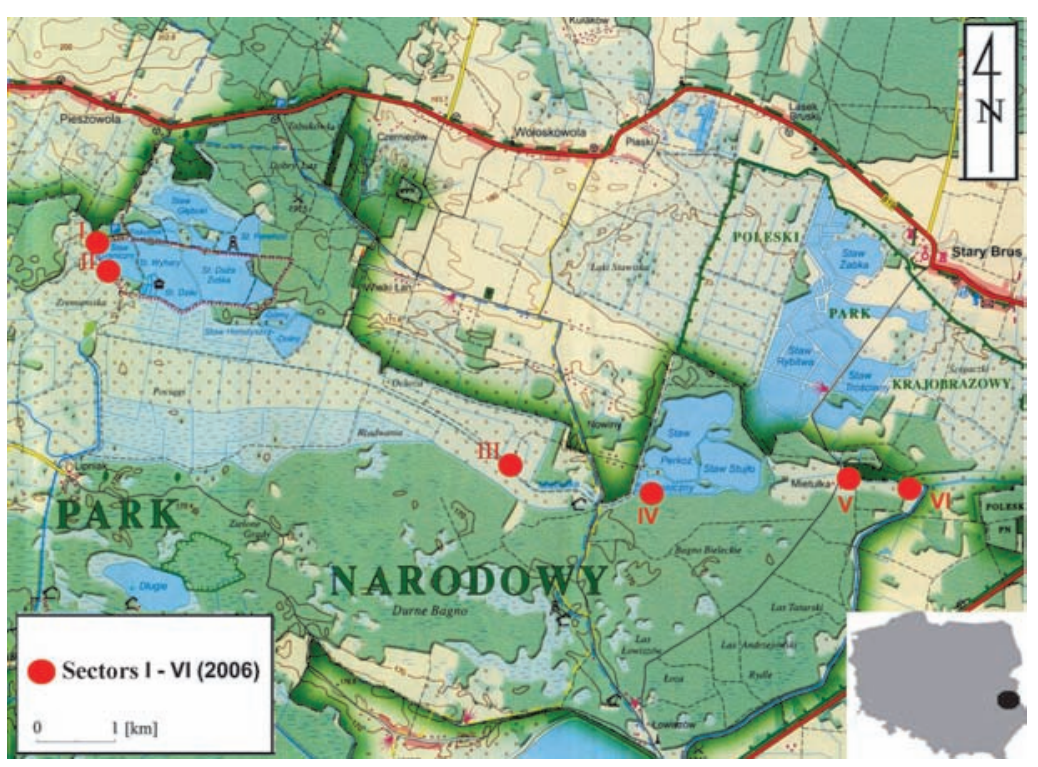

Fig. 1. The location of the study sectors in the Polesie National Park

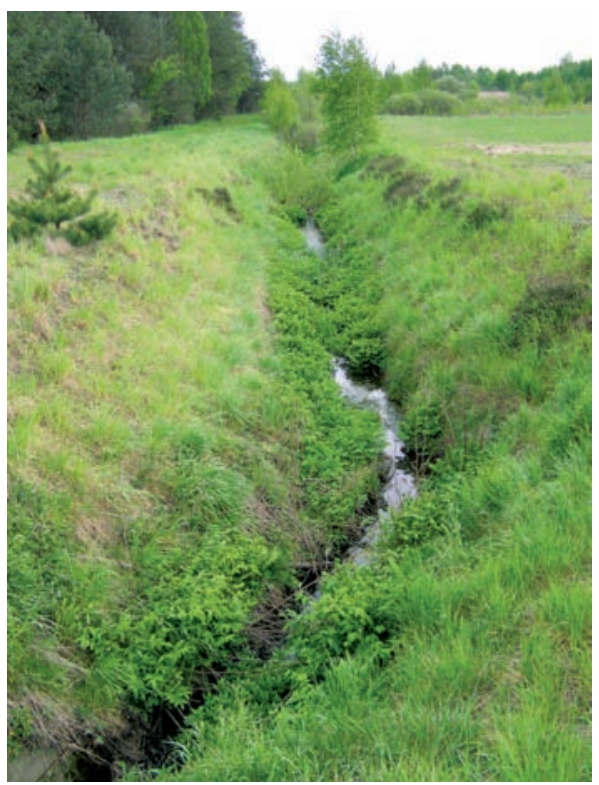

Fig. 2. Sector I - the western part of the Mietiułka River in the Polesie National Park

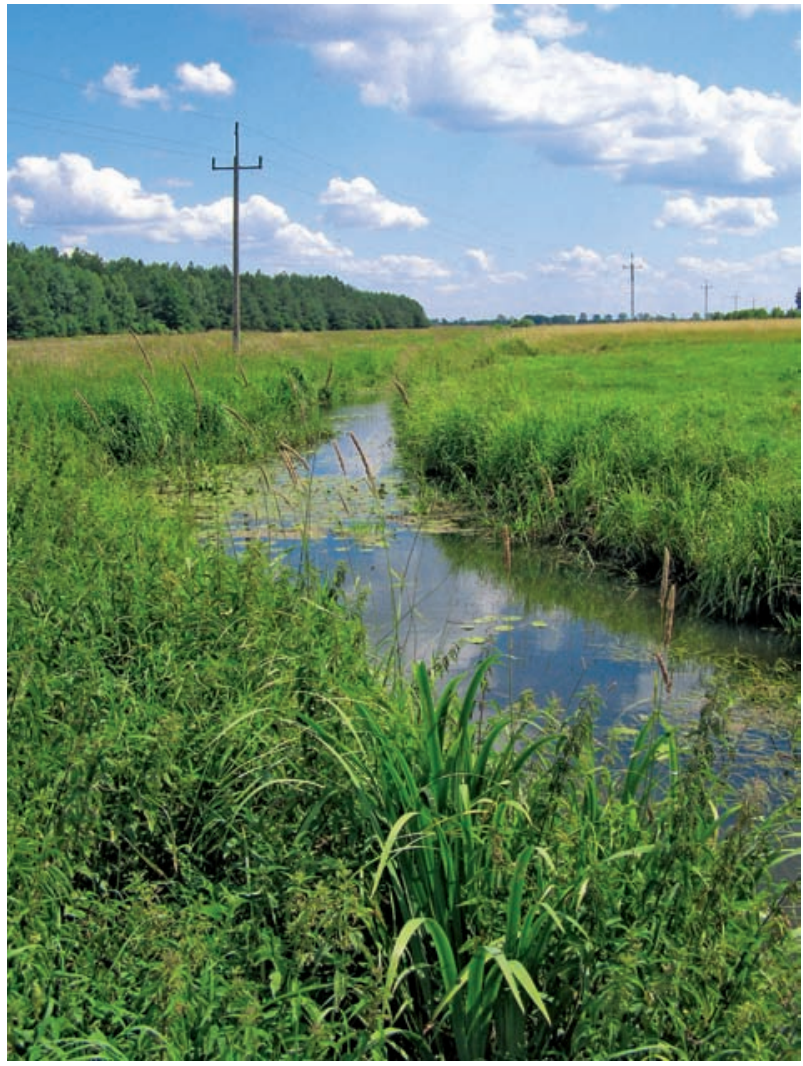

Fig. 3. Sector III - the middle section of the Mietiułka River (Pociągi Meadows)

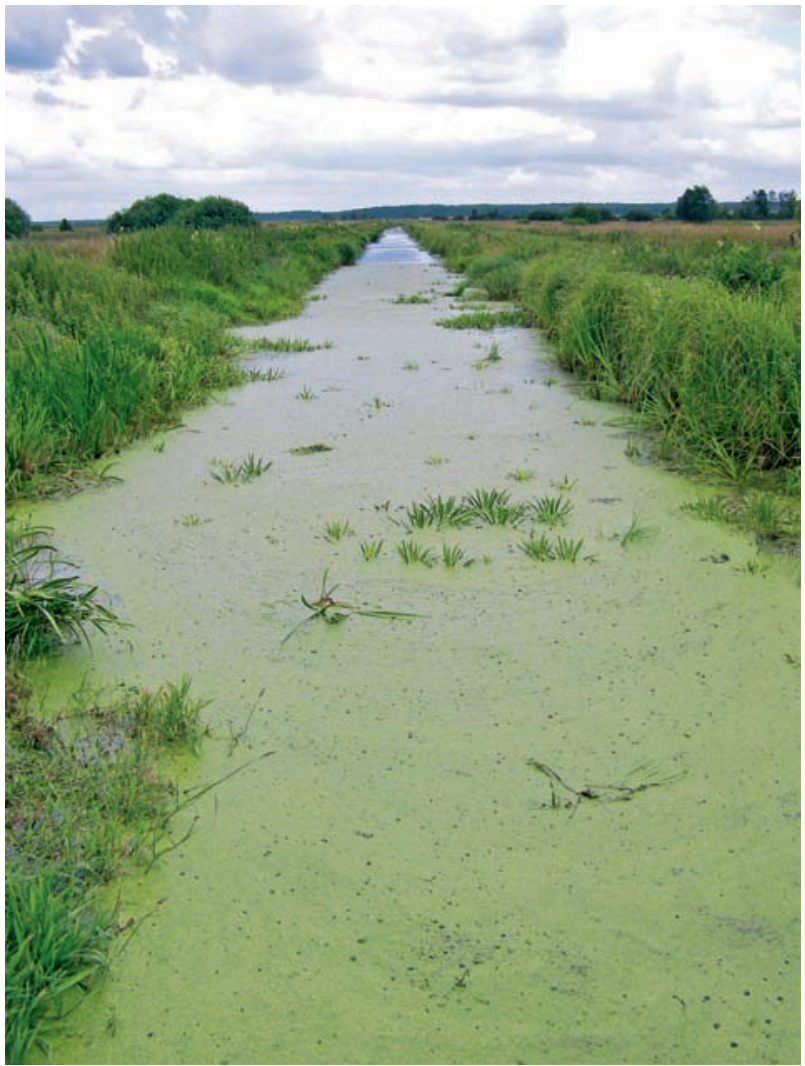

Fig. 4. Sector VI - the mouth section of the Mietiułka River 


\section{DISCUSSION}

The flora of the studied sections of the Mietiulka watercourse is diverse in terms of species as well as in syntaxonomic and ecological terms. It is a mixture of typically aquatic vegetation and vegetation characteristic of the habitats surrounding the river. The species identified in the study area account for $11 \%$ of the entire flora of the Polesie National Park (if we accept the total number of vascular plant species in the PNP following Fijałk ow ski and Izdebski (2002) 1027 taxa). The section of the river which is subjected to continuous human activity is characterized by the lowest floristic diversity, which can be attributable to the initial stage of secondary succession at which the vegetation of this area is.

The results of the study conducted in 2006 were confronted mainly with the results of the studies by B a n a ch et al. (2006) and B a n a ch $(2007,2008$, 2009), who had analysed the species composition of the drainage ditches of the Polesie National Park. The nature of the habitats of the drainage ditches is comparable to the habitats formed by the Mietułka River, primarily due to its anthropogenic nature and the absence of a visible flow of water, rather its stagnation.

In the plant communities of the drainage ditches investigated in the years 2003-2006, in twelve $100 \mathrm{~m}$ long sections (1200 m), the occurrence of 222 higher plant species, belonging to 58 botanical families, was noted. The largest group comprised the species of the following families: Poaceae and Asteraceae, as well as Cyperaceae, Rosaceae and Fabaceae.

Among the macrophyte taxa identified in the flora of the studied sections of the Mietiułka watercourse, the botanical family Poaceae was also represented in greatest numbers, whereas in the western course of the river it was the family Asteraceae. From among the species recorded in all the sectors studied in 2006, 34 species were not found in any of the sections of the drainage ditches investigated by $\mathrm{B}$ a $\mathrm{n} \mathrm{a} \mathrm{ch}$ et al. (2006) and B a n a h (2007, 2009).

In the phytocoenoses of all the study sectors located both in the western and eastern part of the Mietiułka River, the taxa belonging to two syntaxonomic classes, Molinio-Arrhenatheretea and Phragmitetea, were predominant. The proportions of representatives of the other classes were relatively small and they varied. Similar proportions of the species of different syntaxa were documented by B a n a ch (2007) during her study of the phytocoenoses of the drainage ditches, as well as by S a w i k a (2004) during her study of the plant communities found in the drained "Pociągi" nature sanctuary in the Polesie National Park.
Urban and Radwan (2000) noted a large proportion of the communities with a dominance of Glyceria fluitans and Glyceria notata as well as Leersia oryzoides in the drainage ditches and in other small water streams in the Łęczna-Włodawa Lakeland. In the study sectors situated on the Mietiułka River, no occurrence of the abovementioned species was noted at all, and B a n a c h $(2007,2009)$ confirms the occurrence of only one of them in the plant associations of the drainage ditches of the PNP.

Ś więs and Wrzesień (2000) mention that the plant patches with the participation of Urtica dioica within the Park area are exceptionally commonly widespread on the slopes of the old canals and ditches. B a n a ch $(2007,2009)$ confirmed these observations founding that common nettle occurred almost at all the study sites, forming more or less dense aggregations mainly on the slopes of the ditches. On the slopes of the Mietiulka River, the occurrence of this species was also recorded in all the study sectors, however, the most numerous population of Urtica dioica was observed in the watercourse section which had been subjected to the most intense improvements. The occurrence of this nitrophilous species in great abundance at the places where the river regulation works were carried out is caused by a large amount of nitrogen compounds which are released from extracted organic deposits (stored on the edges of the watercourse) undergoing the process of humification and mineralization.

Among the species identified, 19 species were noted in the study area as strongly or totally invasive species, similarly to common nettle (C h m i e 1, 1993a). Elodea canadensis and Urtica dioica occurred in all the study sectors, and Potentilla anserina in five of them.

In order to evaluate the diversity of communities, the so-called biological spectra are used (the number of life forms and life strategies) (F a li ń s k a , 2004). Among the plant life-forms occurring in the studied sections of the Mietiułka River, hemicryptophytes the species characteristic of the temperate zone - dominated by far. The studies of B a n a ch $(2007,2009)$ also indicated the dominance of this group in the habitats of the drainage ditches, and according to $\mathrm{S} z$ a f e $\mathrm{r}$ (1964), this group accounts for more than a half of the species found in the whole of Poland. The proportions of hydro- and helophytes as well as of therophytes in the investigated phytocoenoses of the eastern part of the Mietiulka River were higher than the proportions of these groups in the phytocoenoses of the western part studied in 2006. The abovementioned groups of species accounted for approx. $24 \%$ of all the plant species inhabiting the drainage ditches of the Polesie National Park (B a n a c h, 2007; 2009).

The analysis of the flora of the Mietiułka River sections as well as of the drainage ditches and their 
neighbourhood (B a n a c h , 2007; 2009) as an indicator of continentality showed that the species neutral to continentality were by far predominant. They account for more than $90 \%$ of the flora of the studied habitats.

The qualitative and quantitative proportions of species belonging to different historical-geographical groups can be used as an indicator of the naturalness of the studied flora (C h mi e l, 1993a, 1993b). Spontaneophytes - the taxa which arrived or are native to the study area and can exist there without human intervention - had the largest proportion in the flora of the Mietiułka watercourse studied in 2006 (88.6\% of species) and of the drainage ditches described by Banach (approx. 90\% of species; 2009). Anthropophytes - the species which were introduced in a given area and function there only by human activity, accounted for nearly $2 \%$ in the flora of the drainage ditches of the Polesie National Park, and in the investigated sections of the Mietiułka River their proportion in the flora was only slightly higher, since it was $5.3 \%$. In spite of the fact that drainage ditches are a typically anthropogenic habitat, according to B a n a c h (2007), the lack of maintenance of the channels of the ditches and, in the first place, the establishment of the national park decided about the natural character of the flora of the studied habitats. But the Mietiułka River was significantly transformed by hydraulic works and it flows through the areas with different land uses, including agriculturally used land, hence the habitat differentiation promoting the persistence of both natural and synanthropic species.

The geographic distribution of species is primarily related to their tolerance to the variability of environmental factors in time and space ( $\mathrm{Ch} \mathrm{mie} \mathrm{1,} \mathrm{1993a).}$ The Euro-Siberian species were the dominant range element of the flora of the studied sections of the Mietiułka River, likewise in the flora of the drainage ditches described from the same area located within the Polesie National Park (B a n a c h, 2007; 2009).

The floristically richest phytocoenoses are those functioning in the heterogeneous environments, since no species has an absolute dominance in them (F a l i n s k a , 2004). Such a situation is observed in the habitats which are formed by the channel and slopes of the Mietiułka River. The favourable habitat conditions create advantageous conditions for the functioning of the diverse flora, in whose species composition rare and protected species can also be encountered.

\section{REFERENCES}

Banach B., Pogorzelec M., Sczurowska A., 2006. Vascular plant soft drainage ditches and adjacent habitats In the Poleski national Park and their protection. Acta Agrophysica, 7 (2):297-301
B a n a c h B., 2007. Różnorodność gatunkowa flory rowów melioracyjnych w Poleskim Parku Narodowym i w jego otulinie. / The species diversity of the flora of drainage ditches in the Polesie National Park and its buffer zone. Rozprawa doktorska. Maszynopis w Katedrze Ekologii Ogólnej Uniwersytetu Przyrodniczego w Lublinie. Lublin (in Polish).

B a n a ch B., 2008. Rare and protected species in the drainage ditches and adjacent phytocoenoses in the Polesie National Park. Acta Agrobot. 61 (2): 103-111.

$\mathrm{B}$ a n a ch B., 2009. Vascular flora of drainage ditches in forest area of the Polesie National Park. Acta Agrobot. 62 (1): 117-126.

Cebrykow P., Grzechnik L., Kałamucki K., 2001. Polesie National Park. Tourist map 1:50000. Kartpol s.c., Lublin.

Chmiel J., 1993 a. Flora roślin naczyniowych wschodniej części Pojezierza Gnieźnieńskiego i jej antropogeniczne przeobrażenia w wieku XIX i XX. Część I. Sorus, Poznań (in Polish).

Chmiel J., 1993 b. Flora roślin naczyniowych wschodniej części Pojezierza Gnieźnieńskiego i jej antropogeniczne przeobrażenia w wieku XIX i XX. Część II. Atlas rozmieszczenia roślin. Sorus, Poznań (in Polish).

Chmielewski T. J., Sielewicz B., 1994. Ekologiczna waloryzacja terenu. [In:] S. Radwan (ed.), Środowisko przyrodnicze w strefie oddziaływania kanału WieprzKrzna, TWWP, Lublin (in Polish).

Fa 1 i ńs k a K., 2004. Ekologia roślin. PWN, Warszawa (in Polish).

Fijałkowski D., Izdebski K., 2002. Flora Poleskiego Parku Narodowego - Flora Naczyniowa. [In:] S. Radwan (ed.), Poleski Park Narodowy monografia przyrodnicza. Wyd. Morpol, Lublin, 103-114 (in Polish).

Ja nie c B., 1994. Wpływ Kanału Wieprz-Krzna na przenoszenie zanieczyszczeń do środowiska wodnego. [In:] S. Radwan (ed.), Środowisko przyrodnicze w strefie oddziaływania kanału Wieprz-Krzna. TWWP, Lublin (in Polish).

Kornijów R., 1999. Plan ochrony PPN. Operat ochrony zasobów i ekosystemów wodnych. Cz. II - Ekosystemy wodne, Maszynopis w Poleskim Parku Narodowym. / The manuscript at the Polesie National Park. Warszawa (in Polish).

Łoś M. J., 1992. Wpływ systemu Kanału Wieprz-Krzna na stosunki wodne i zróżnicowanie ekologiczne w Poleskim Parku Narodowym i jego otulinie. [In:] Ochrona ekosystemów wodnych w PPN i jego otulinie, Tom II. Maszynopis w Poleskim Parku Narodowym. Lublin (in Polish).

Łoś M. J., 1995. Wpływ systemu Kanału Wieprz-Krzna na stosunki wodne w Poleskim Parku Narodowym. [In:] S. Radwan (ed.), Ochrona ekosystemów wodnych w Poleskim Parku Narodowym i jego otulinie, TWWP, Lublin (in Polish).

M a t u s z k i ew i c z W., 2001. Przewodnik do oznaczania zbiorowisk roślinnych Polski. Państwowe Wydawnictwo Naukowe, Warszawa (in Polish). 
Michalczyk Z., Bartoszewski S., Chmiel S., Dawidek J., Głowacki S., Turczyński M., 2002. Zasoby wodne Poleskiego Parku Narodowego. [In:] Poleski Park Narodowy. Monografia Przyrodnicza. S. Radwan (ed.). Wydawnictwo MORPOL, Lublin.

Michalczyk Z., Bartoszewski S., Turczyński M., Chmiel S., Dawidek J., Głowacki S., Zielińska B., 1999. Plan ochrony PPN. Operat ochrony zasobów i ekosystemów wodnych. Cz. I - Zasoby wodne. The Polesie National Park conservation plan. A conservation appraisal of water resources and aquatic systems. Part I - Water resources. Maszynopis w Poleskim Parku Narodowym. Warszawa (in Polish).

Mirek Z., Piękoś-Mirkowa H., Zając A., Zając M., 2002. Flowering Plants and Pteridophytes of Poland. A Checklist. W. Szafer Institute of Botany, Polish Academy of Science, Kraków.

Piasecki D., 2005. Historia powstania i 15 lat działalności Poleskiego Parku Narodowego. [In:] T. J. Chmielewski (ed.), 15 lat Poleskiego Parku Narodowego. Monografia. Wydawnictwo PPN, Warszawa, Lublin, Urszulin (in Polish).

Rut kowski B., 2001. Klucz do oznaczania roślin naczyniowych Polski niżowej. Państwowe Wydawnictwo Naukowe, Warszawa (in Polish).

S a w i ck a A., 2004. Analiza zmian warunków hydrologicznych i środowiskowych na obiekcie „Łąki Pociągi” na obszarze Poleskiego Parku Narodowego. Praca magisterska. Maszynopis w Poleskim Parku Narodowym. / An analysis of the changes in the hydrological and environmental conditions at the "Pociagi Meadows" site in the Polesie National Park area. Master's thesis. The manuscript at the Polesie National Park. Warszawa (in Polish).

S z a fer W., 1964. Ogólna geografia roślin. Państwowe Wydawnictwo Naukowe, Warszawa (in Polish).

Święs F., Wrzesień M., 2000. Ekosystemy synantropijne w Poleskim Parku Narodowym. [In:] S. Radwan, Z. Lorkiewicz (eds), Problemy ochrony i użytkowania obszarów wiejskich o dużych walorach przyrodniczych. Wydawnictwo UMCS, Lublin: 263-277 (in Polish).

Urban D., Radwan S., 2000. Ekosystemy torfowiskowe. [In:] T. J. Chmielewski (ed.), Międzynarodowy Rezerwat Biosfery „Polesie Zachodnie”. PPN, Lublin: 43-45 (in Polish).

W y s o ck i C., S i k or sk i P., 2002. Fitosocjologia stosowana. Wyd. SGGW, Warszawa (in Polish).

Zarzycki K., Trzcińska-Tacik H., Różański W., Szeląg Z., Wołek J., Korzeniak U., 2002. Ecological Indicator Values of Vascular Plants of Poland, W. Szafer Institute of Botany, Polish Academy of Science, Kraków.

\section{Bogactwo gatunkowe flory wybranych fragmentów rzeki Mietiułki w Poleskim Parku Narodowym}

\section{Streszczenie}

Celem badań była waloryzacja przyrodnicza 6 wybranych fragmentów zmeliorowanej rzeki Mietiukki obejmująca inwentaryzację i analizę flory naczyniowej związanej bezpośrednio z ciekiem. Wyniki badań wykazały, że flora badanego terenu jest zróżnicowana pod względem taksonomicznym, syntaksonomicznym i ekologicznym, a w jej skład wchodzą zarówno rośliny typowo wodne jak i gatunki charakterystyczne dla otaczających rzekę siedlisk. We florze sektorów badań oznaczono łącznie 114 gatunków roślin naczyniowych z 42 rodzin botanicznych, 15 klas syntaksonomicznych, charakteryzujących się przynależnością do różnych grup ekologicznych. W składzie gatunkowym flory wszystkich sektorów badań wyraźnie dominowały hemikryptofity, sponteneofity, gatunki neutralne wobec kontynentalizmu oraz gatunki zaliczane do jednostki fitogeograficznej elementów borealnych: podelementu eurosyberyjskiego. Największym udziałem charakteryzowały się makrofity pospolicie występujące w Polsce. Odnotowano jeden gatunek o małej liczbie stanowisk w kraju - kropidło piszczałkowate (Oenanthe fistulosa) oraz 2 gatunki narażone na wyginięcie Sagittaria sagittifolia i Hypochoeris glabra. 
